\title{
Geologia da região de Jequeri-Viçosa (MG), Orógeno Araçuaí Meridional
}

\author{
Daniel Tavares Gradim ${ }^{1 *}$, Gláucia Nascimento Queiroga ${ }^{2}$, Tiago Amâncio Novo ${ }^{1}$, \\ Carlos Maurício Noce ${ }^{1 * *}$, Antônio Carlos Pedrosa-Soares ${ }^{1}$, Antônio Wilson Romano ${ }^{1}$, \\ Maximiliano Martins ${ }^{1}$, Fernando Flecha de Alkmim² ${ }^{2}$ Camila Franco Basto ${ }^{2}$, \\ Moisés Abraão Suleimam ${ }^{1}$
}

1. CPMTC-IGC-UFMG, Campus Pampulha, Belo Horizonte, MG. *Mestrando em Geologia, UFMG. danieltgradim@gmail.com,
**In Memoriam.

2. DEGEO-Escola de Minas-UFOP, Campus Morro do Cruzeiro, Ouro Preto, MG.

Recebido em 18/10/2011; aceito em 14/11/2011

RESUMO: A característica fundamental da região de Jequeri-Viçosa, situada no extremo sul do Orógeno Araçuaí, é a abundância de rochas metamórficas, ortoderivadas e paraderivadas, de fácies anfibolito alto e granulito. $\mathrm{O}$ embasamento paleoproterozóico é representado, a oeste, por ortognaisses tonalíticos a graníticos do Complexo Mantiqueira e, a leste, por ortognaisses charno-enderbíticos do Complexo Juiz de Fora. Ambos os complexos incluem anfibolitos e exibem intensidades variáveis de migmatização. O contato entre eles é marcado pela zona de cisalhamento transpressiva destral de Abre Campo, interpretada como uma sutura paleoproterozóica reativada no Neoproterozóico. O Anfibolito Santo Antônio do Grama e rochas meta-ultramáficas associadas (Córrego do Pimenta) representam restos ofiolíticos ediacaranos, colocados ao longo da Zona de Cisalhamento de Abre Campo. Assentada sobre o embasamento, na parte oeste da área, ocorre uma associação metavulcano-sedimentar neoproterozóica do Grupo Dom Silvério, composta por xistos diversos e quartzito. Na porção leste da área mapeada, a cobertura metassedimentar neoproterozóica é atribuída ao Grupo Andrelândia que inclui paragnaisse migmatítico e raro quartzito. Corpos de hidrotermalito quartzoso, indiscriminadamente associados às unidades do embasamento e da cobertura neoproterozóica, ocorrem ao longo de zonas de cisalhamento. Hidrotermalitos ferruginosos associam-se ao Complexo Mantiqueira na Zona de Cisalhamento de Ponte Nova. O granito foliado a milonitizado da Serra dos Vieiras parece ser um produto de fusão parcial do paragnaisse Andrelândia. Completam o quadro geológico os pegmatitos da Suíte Paula Cândico e diques de diabásio mesozóicos.

Palavras-chave: Paleoproterozóico, Neoproterozóico, Orógeno Araçuaí

ABSTRACT: GEOLOGY OF THE JEQUERI-VIÇOSA REGION, MINAS GERAIS STATE, SOUTHERN ARAÇUAÍ OROGEN. This Paper focuses on the southwestern sector of the Araçuaí orogen in a region located close to the boundary with the northern Ribeira orogen. This region is rich in ortho- and para-derived metamorphic rocks of the high amphibolite and granulite facies. The Paleoproterozoic basement includes, to the west, tonalitic to granitic orthogneisses of the Mantiqueira Complex and, to the east, enderbitic to charnockitic orthogneisses of the Juiz de Fora Complex. Both complexes also include amphibolite enclaves and show several rates of partial melting. The contact between them is marked by the dextral transpressional Abre Campo shear zone, considered to be a Paleoproterozoic suture reactivated during the Neoproterozoic Era. The Santo Antônio do Grama Amphibolite and associated meta-ultramafic rocks (Córrego do Pimenta) are Ediacaran ophiolite slivers emplaced along the Abre Campo shear zone. In the western part of the region, the Paleoproterozoic basement is locally covered by a metavolcano-sedimentary assemblage composed of amphibolite facies schist and quartzite of the Neoproterozoic Dom Silvério Group. To the east, the Neoproterozoic cover comprises the migmatized paragneiss and rare quartzite of the Andrelândia Group. The Serra dos Vieiras foliated to mylonitic granite seems to be formed from the partial melting of the Andrelândia paragneiss. Pegmatites of the Paula Cândido Suite and Mesosozic diabase dikes complete the geologic framework of the mapped area.

Keywords: Paleoproterozoic, Neoproterozoic, Araçuaí Orogen

\section{INTRODUÇÃO}

O sistema orogênico brasiliano representado pela Província Mantiqueira (Brito-Neves et al. 1999, Almeida et al. 2000) inclui o Orógeno Araçuaí como seu setor setentrional, limitado a sul pelo Orógeno Ribeira, e a norte e oeste pelo Cráton do São Francisco (Pedrosa-Soares et al. 2001, 2007; Heilbron et al. 2004). A região estudada situa-se no extremo sul do Orógeno Araçuaí, e compreende as áreas das folhas do IBGE denominadas Jequeri 1:50.000 e Viçosa 1:100.000 (Fig. 1). Estas folhas foram mapeadas no âmbito de um contrato CPRMUFMG-Programa Geologia do Brasil.

A região é dominada por rochas metamórficas de fácies anfibolito e granulito, ortoderivadas e paraderivadas, do Paleoproterozóico e Neoproterozóico, e por grandes zonas de cisalhamento. A orogenia brasiliana impôs a arquitetura tectônica final da região, após modificar, parcial a totalmente, feições geradas por orogenias anteriores (Brandalise 1991; Leite et al. 2004; Peres et al. 2004; Alkmim et al. 2006; Noce et al. 2007a,b; Gradim et al. 2011; Queiroga et al. 2011).

Com base no estudo de cerca de dois mil afloramentos rochosos, situados nas áreas das folhas Jequeri e Viçosa (Queiroga et al. 2011 e Gradim et al. 2011), este artigo apresenta uma síntese sobre a estratigrafia, geologia estrutural e metamorfismo desta região do Orógeno Araçuaí (Fig. 1).

\section{ESTRATIGRAFIA}

$\mathrm{Na}$ área coberta pelas folhas Jequeri e Viçosa são individualizados, como conjuntos maiores, as unidades do embasamento paleoproterozóico (complexos Mantiqueira e Juiz de Fora) e sua cobertura neoproterozóica (grupos Andrelândia e Dom Silvério) (Tabela 1). Além disto, ocorrem rochas metamáficas (Santo Antônio do Grama), ultramáficas (Córrego do Pimenta), graníticas (Corpo 


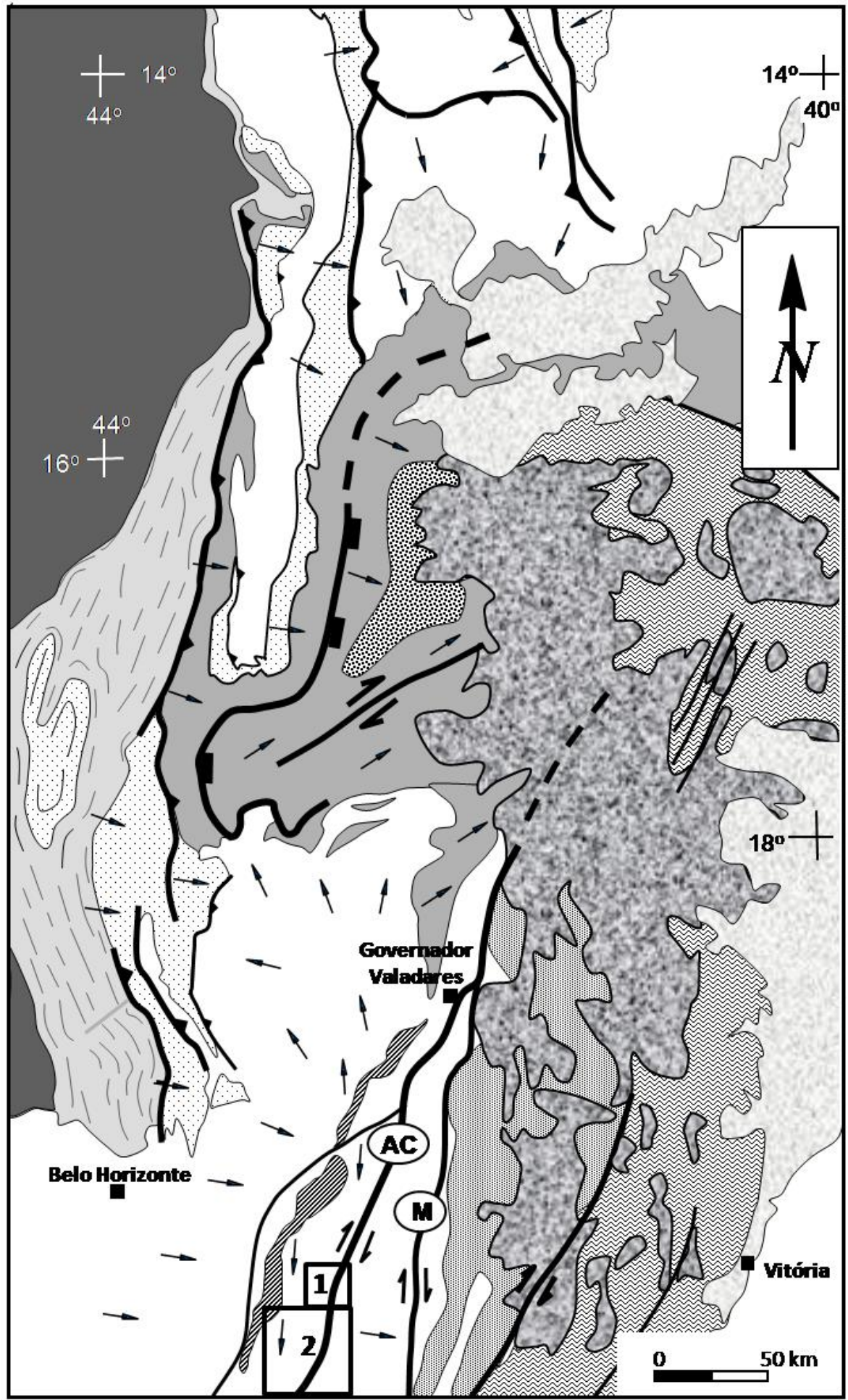

Cobertura fanerozoica

Plutonismo orogenico

ediacarano

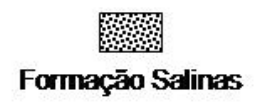

Grupo Rio Doce

Complexos paragnáissicos

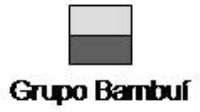

Grupo Macachas

Grupo Dom Silvério

Supergrupo Espinhaço

Embasamento e unidades nāo discriminadas

ZONAS DECISALHAMENTO \& Reversa (Normal

$1 / l$ Transcorrente

- Lineaçãode estiramento

Folhas mapeadas:

1, Jequeri 1:50.000;

2, Viçosa 1:100.000

(contrato CPRM-UFMG)

Figura 1. Localização da região de Jequeri-Viçosa no mapa tectônico esquemático do Orógeno Araçuaí (modificado de Alkmim et al. 2006, 2007). Zonas de cisalhamento indicadas com siglas: AC, Abre Campo; M, Manhuaçu.

Figure 1. Location of the Jequeri-Viçosa region in the sketch tectonic map of the Araçuai Orogen (modified from Alkmim et al. 2006, 2007). Shear zones indicated in the map: AC, Abre Campo; M, Manhuaçu. 
Tabela 1. Resumo das características macroscópicas e microscópicas das principais rochas encontradas na região de Jequeri-Viçosa (Opx = ortopiroxênio; $\mathrm{Cpx}=$ clinopiroxênio; $\mathrm{Hbl}=$ hornblenda; $\mathrm{Anf}$ = anfibólio; $\mathrm{Hy}=$ hercynita; $\mathrm{Cl}$ = clorita magnesiana; Grt = Granada; $B t=$ biotita; Sil = sillimanita; $M c=$ microclina; $K f p=K$-feldspato; $P I=$ plagioclásio; $Q z=$ quartzo; Ttn = titanita; Opq = opacos; Zrn = zircão; $A p=$ apatita $)$.

Table 1. Summary of macroscopic and microscopic features of the main rocks found in the Jequeri-Viçosa region (OPX = orthopyroxene,

$\mathrm{Cpx}=$ clinopyroxene, $\mathrm{Hbl}=$ hornblende; $\mathrm{Amph}=$ amphibole; $\mathrm{Hy}=$ hercynite; $\mathrm{Cl}=$ magnesian chlorite, $\mathrm{Grt}=\mathrm{Garnet}, \mathrm{Bt}=$ biotite,

Sil = sillimanite, $M c=$ microcline $; K F P=K$-feldspar, $P I=$ plagioclase,$Q z=$ quartz; $T T N=$ titanite, $O P Q=$ opaque; $Z r n=z i r c o n, A p=a p a t i t e)$

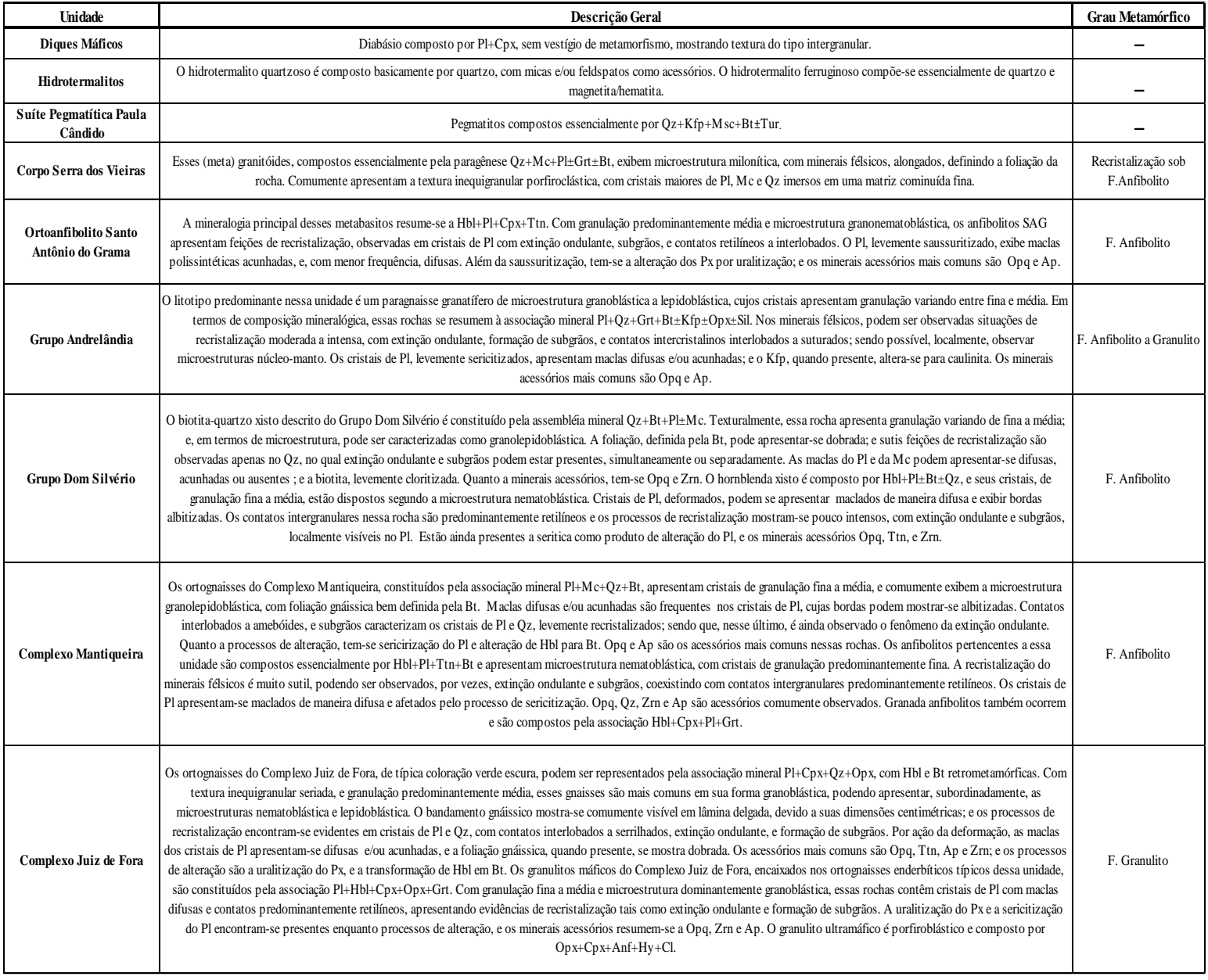

Serra dos Vieiras) e pegmatíticas (Suíte Paula Cândido), todas neoproterozóicas, e unidades litológicas formadas por hidrotermalismo em zonas de cisalhamento, diques máficos mesozóicos e aluviões recentes (Fig. 2, 3 e 4). Uma síntese das descrições dessas unidades encontra-se na Tabela 1.

\section{1 - Embasamento}

Uma importante feição morfotectônica, a Zona de Cisalhamento de Abre Campo, destaca-se na região e separa os domínios maiores do embasamento: a oeste, o Complexo Mantiqueira e, a leste, o Complexo Juiz de Fora (Fig. 2, 3 e 4).

\subsection{1 - Complexo Mantiqueira}

A rocha largamente predominante nesta unidade é um anfibólio-biotita ortognaisse bandado, de composição predominantemente granodiorítica a granítica, subordinadamente tonalítica, migmatizado em intensidades diversas (Fig. 5A e 6A). As estruturas migmatíticas mais comuns são do tipo dobrada, estromática, schöllen, schlieren, ptigmática e surreítica. $O$ bandamento varia de centimétrico a decimétrico e é marcado pela alternância de bandas félsicas, quartzo-feldspáticas, e bandas máficas ricas em biotita e/ou hornblenda. Muitas vezes, este bandamento está dobrado, apresentando dobras apertadas a abertas (Fig. 5A). O ortognaisse é essencialmente constituído de quartzo (35-40\%), plagioclásio (20-25\%), biotita (20\%), microclina (5$15 \%)$ e hornblenda (10\%). Os minerais acessórios mais comuns são zircão, apatita, titanita, allanita e minerais opacos.

Os corpos anfibolíticos de dimensões decamétricas ou maiores foram individualizados em mapa e se encontram dispersos na área de ocorrência do Complexo Mantiqueira (Fig. 2 e 3). Entretanto, estes corpos ocorrem mais frequentemente na forma de bandas e/ou boudins, 


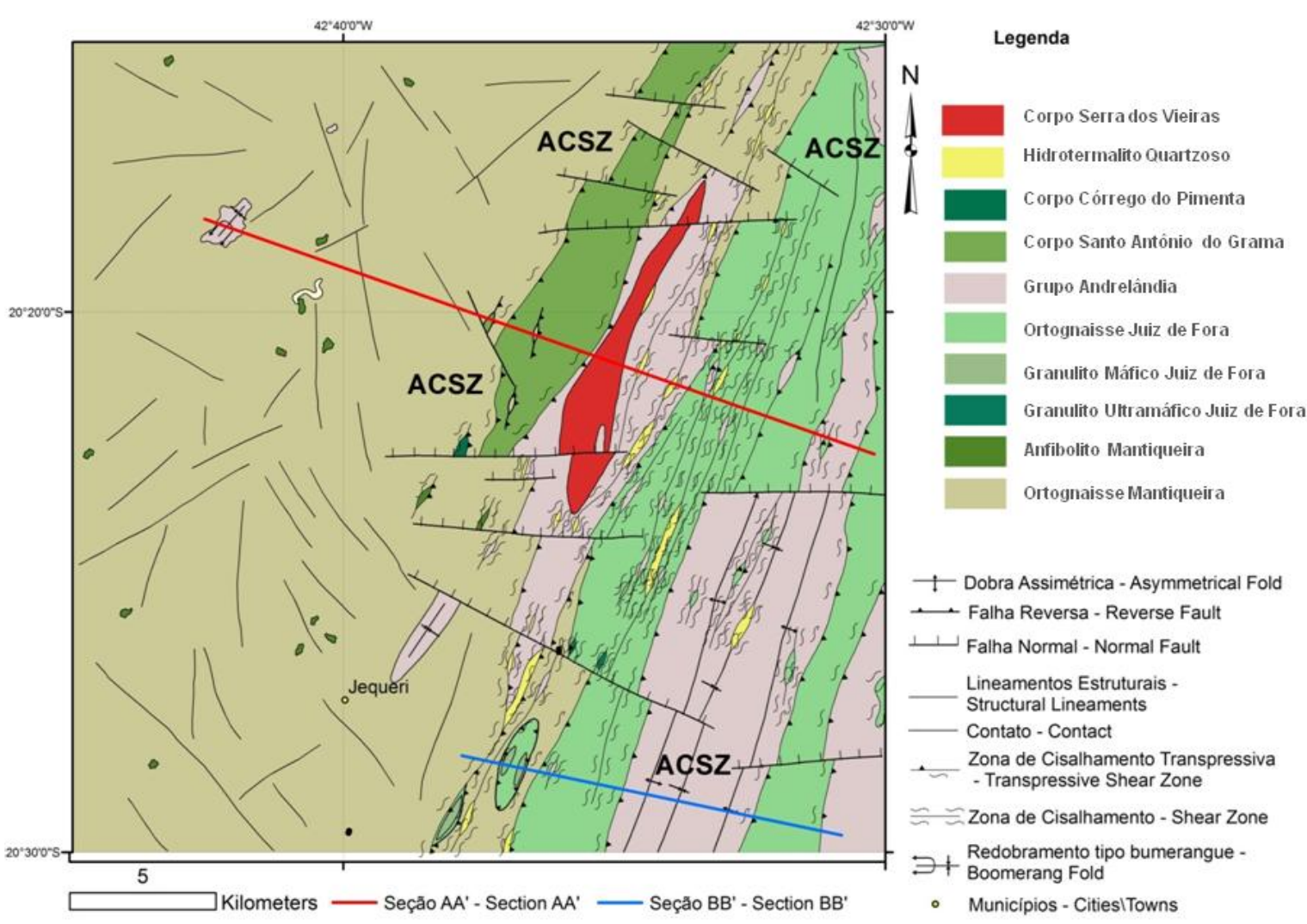

Figura 2. Mapa geológico da Folha Jequeri (simplificado de Queiroga et al. 2011). ACSZ, zona de cisalhamento de Abre Campo.

Figure 2. Geologic map of the Jequeri area (simplified from Queiroga et al. 2011). ACSZ, Abre Campo shear zone.

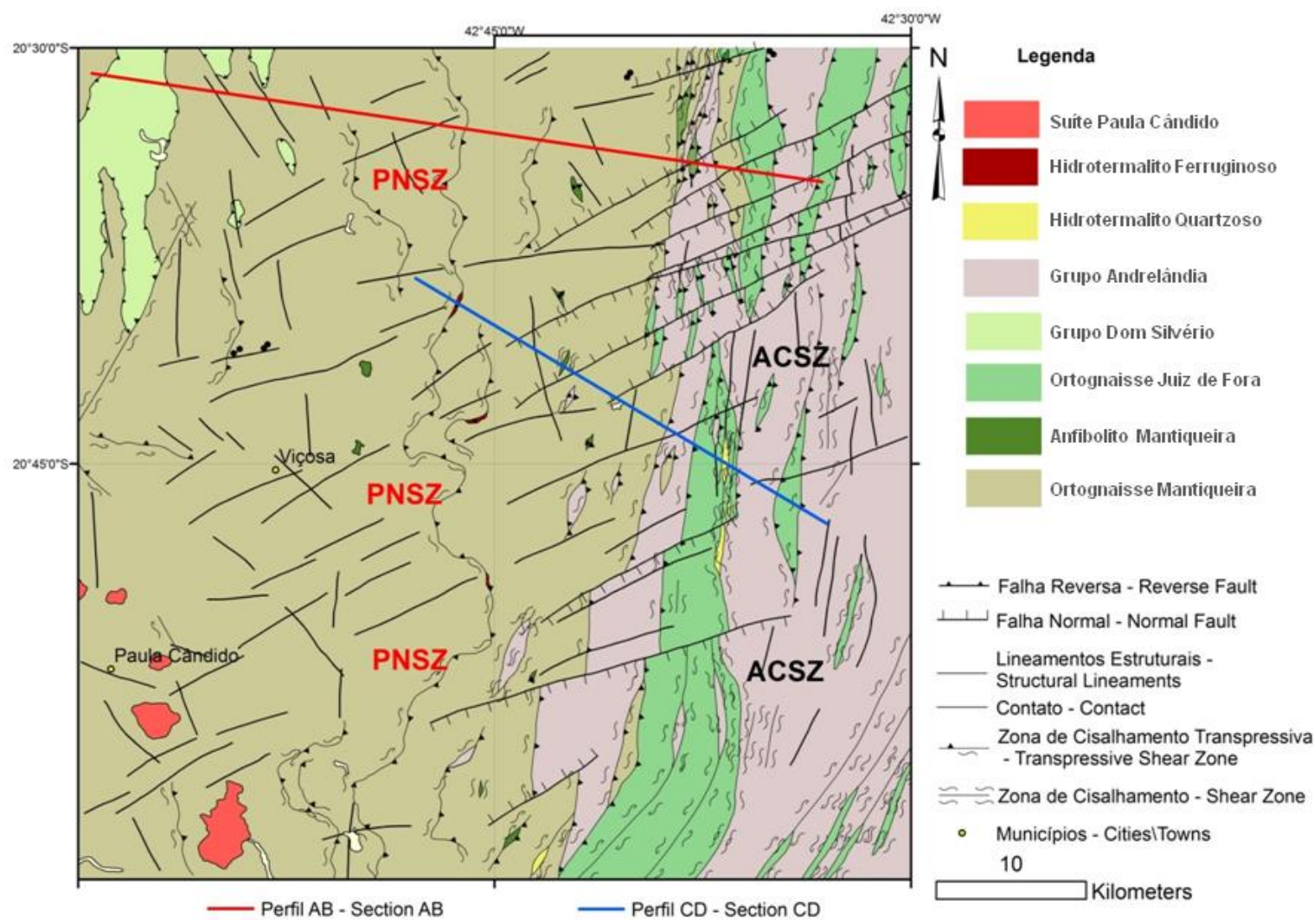

Figura 3. Mapa geológico da Folha Viçosa (simplificado de Gradim et al. 2011). ACSZ, zona de cisalhamento de Abre Campo; PNSZ, zona de cisalhamento de Ponte Nova.

Figure 3. Geologic map of the Viçosa area (simplified from Gradim et al. 2011). ACSZ, Abre Campo shear zone; PNSZ, Ponte Nova shear zone. 


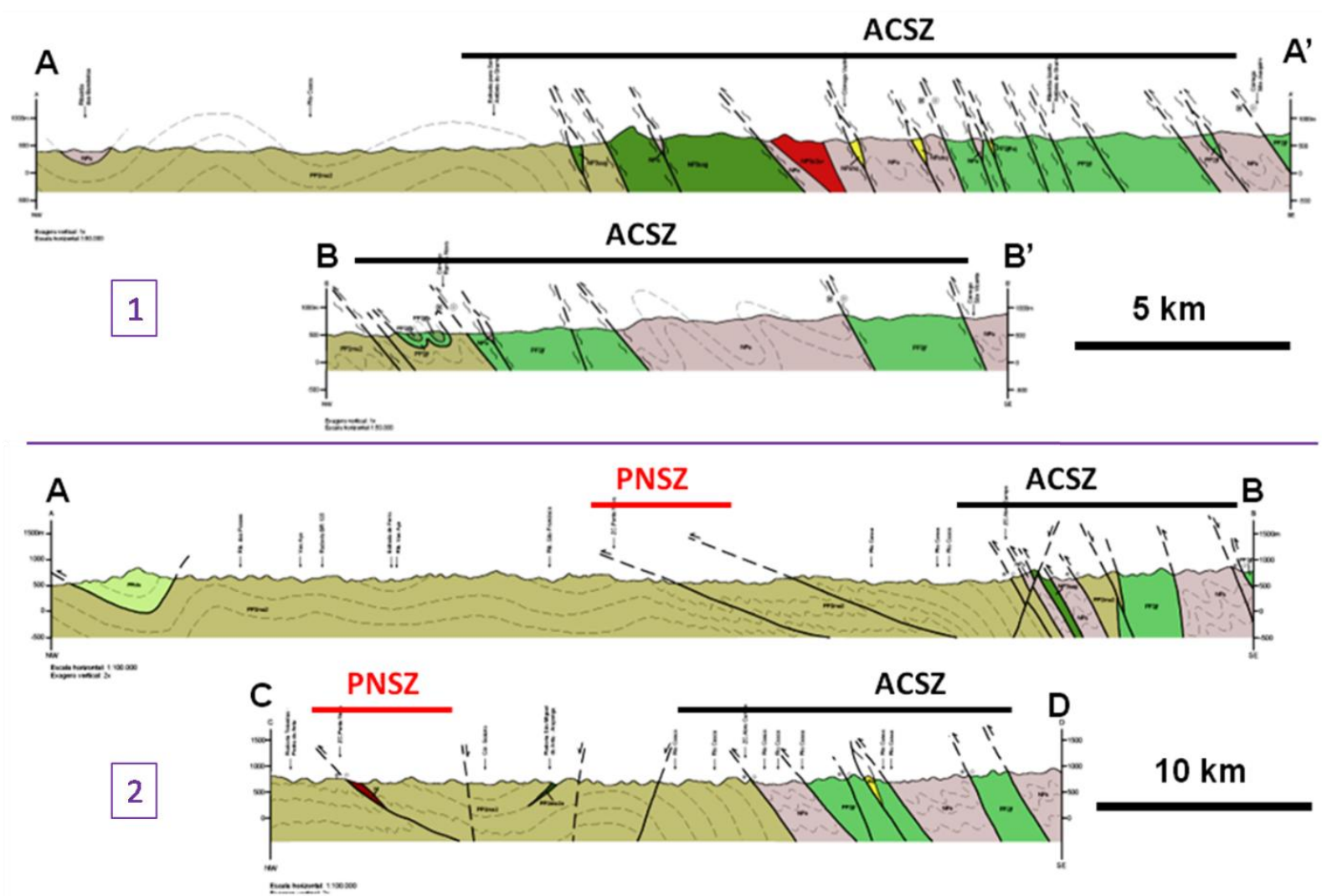

Figura 4. Seções transversais ilustrando a arquitetura tectônica das áreas de Jequeri (1, Queiroga et al. 2011) e Viçosa (2, Gradim et al. 2011). ACSZ, zona de cisalhamento de Abre Campo; PNSZ, zona de cisalhamento de Ponte Nova.

Figure 4. Cross-sections illustrating the tectonic architecture of the Jequeri (1, Queiroga et al. 2011) and Viçosa (2, Gradim et al. 2011) areas. ACSZ, Abre Campo shear zone; PNSZ, Ponte Nova shear zone.

centimétricos a decimétricos, intercalados no ortognaisse Mantiqueira. $\mathrm{O}$ orto-anfibolito mais comum neste complexo é um litotipo bandado e/ou foliado, composto de hornblenda, plagioclásio cálcico, titanita e biotita (Fig. 5B e 6B). Outra variedade de orto-anfibolito, com clinopiroxênio e granada, ocorre em poucos afloramentos nos extremos norte e nordeste das folhas Jequeri e Viçosa, respectivamente.

Corpos pegmatíticos de composição granítica e veios de quartzo com cristais centimétricos de biotita, não mapeáveis nas escalas dos mapas, são freqüentes no Complexo Mantiqueira.

\subsection{2 - Complexo Juiz de Fora}

Este complexo ocorre em escamas tectônicas intercaladas principalmente no Grupo Andrelândia, mas também no Complexo Mantiqueira (Fig. 4). Na região estudada, o Complexo Juiz de Fora é composto por gnaisse enderbítico, granulito máfico e granulito ultramáfico (Fig. 2 e 3).

O gnaisse enderbítico é o litotipo predominante na área mapeada. Trata-se de um ortognaisse esverdeado, mas que perde esta cor a mínima alteração intempérica. Exibe bandamento centimétrico a decimétrico, marcado pela alternância de bandas mais e menos félsicas (Fig. 5C). A frequente migmatização é representada por leucossoma quartzo-feldspático de composição charnockítica e granulação grossa, e melanossoma enderbítico de granulação fina a média. A composição mineralógica do ortognaisse enderbítico consiste de quartzo (20-40\%), plagioclásio (20-30\%), hiperstênio (10-30\%), hornblenda (10-20\%) e biotita (5-20\%). Clinopiroxênio, zircão, apatita e minerais opacos são os acessórios mais comuns (Fig. 6C).

O granulito máfico é uma rocha comum no Complexo Juiz de Fora. Ocorre na forma de intercalações boudinadas, centimétricas a métricas, alongadas paralelamente à foliação regional do ortognaisse enderbítico. Localmente, forma corpos mais expressivos, estirados segundo a direção NE, como nas proximidades da Zona de Cisalhamento de Abre Campo, na Folha Jequeri (Fig. 2). Trata-se de uma rocha verde escura, maciça a fracamente foliada, com granulação variável entre fina e média. A composição essencial do granulito máfico é dada por hiperstênio, clinopiroxênio, plagioclásio e granada (Fig. 6E). A mineralogia acessória inclui quartzo, zircão, apatita e minerais opacos. Biotita e hornblenda são produtos de alteração retrometamórfica. 

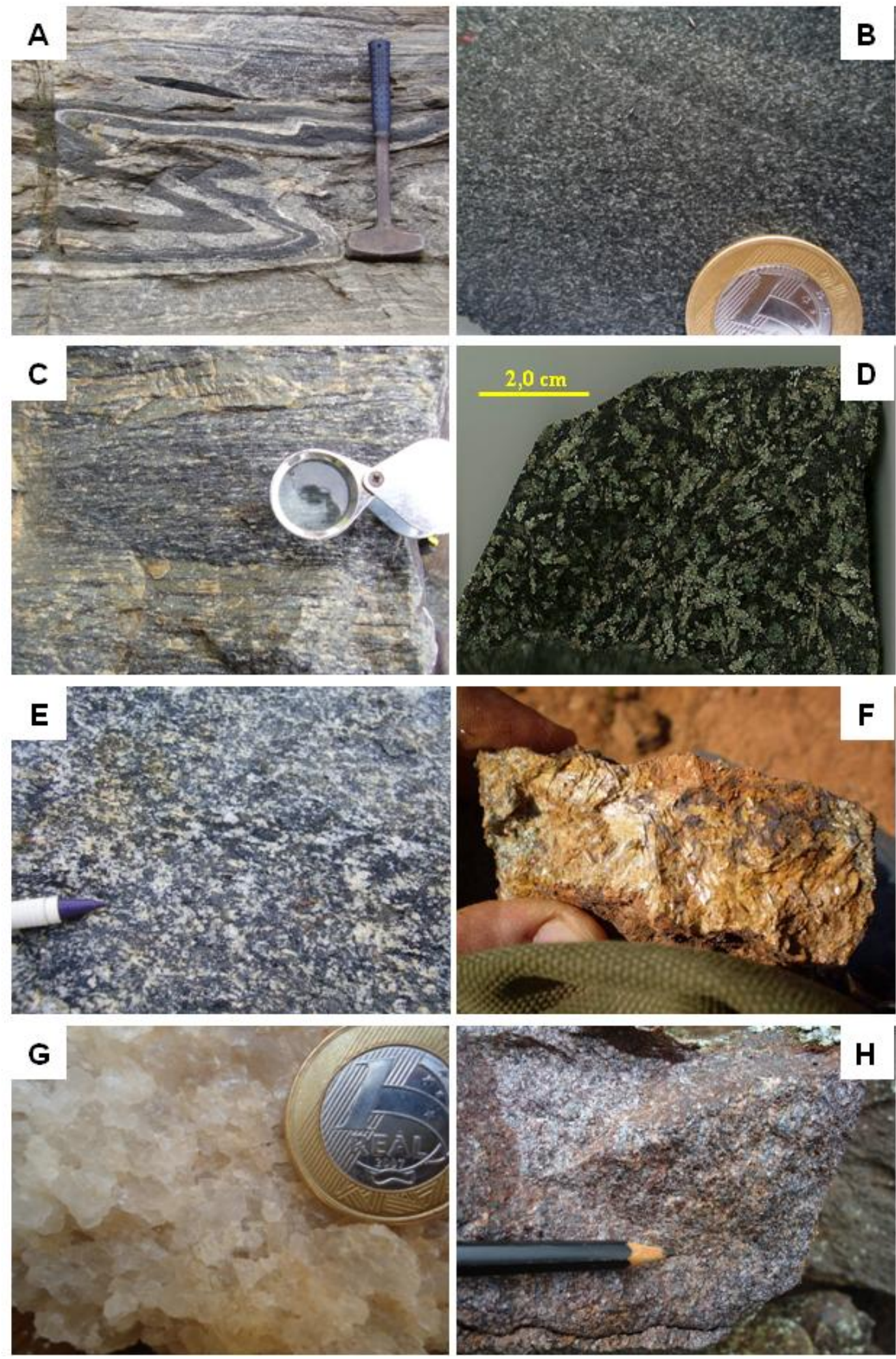

Figura 5. Fotografias de afloramentos e amostras de mão: A, ortognaisse do Complexo Mantiqueira, dobrado e com bandas máficas; $B$ anfibolito do Complexo Mantiqueira; $C$, ortognaisse granulítico esverdeado do Complexo Juiz de Fora; $D$, granulito ultramáfico, com ripas de ortopiroxênio, do Complexo Juiz de Fora; E, ortoanfibolito Santo Antônio do Grama; F, antofilita-talco xisto do Corpo Meta-ultramáfico Córrego do Pimenta; $G$, hidrotermalito quartzoso com a típica textura sacaroidal ; $H$, hidrotermalito ferruginoso.

Figure 5. Photos from outcrops and hand samples: A, folded orthogneiss of the Mantiqueira Complex, with mafic bands; $B$, amphibolite of the Mantiqueira Complex; $C$, greenish granulitic orthogneiss of the Juiz de Fora Complex; $D$, ultramafic granulite with laths of orthopyroxene of the Juiz de Fora Complex; E, Santo Antônio do Grama orto-amphibolite; F, anthophyllite-talc schist of the Córrego do Pimenta metaultramafic body, G: quartz-rich hydrothermalite and its typical saccharoidal texture; $\mathrm{H}$, iron-rich hydrothermalite. 
Pequenos corpos de rocha ultramáfica metamorfizada (Fig. 5D e 6D), denominada granulito ultramáfico (Queiroga et al. 2011), foram cartografados nas proximidades do povoado de Grota, a leste de Jequeri (Fig. 2). Trata-se de uma rocha foliada, porfiroblástica, composta predominantemente por anfibólio bege claro, ortopiroxênio, clinopiroxênio, hercynita e clorita magnesiana (clinocloro). Cristais de quartzo, ocupando espaços intersticiais, ocorrem em pequena quantidade. Em determinadas porções, o ortopiroxênio apresenta-se esqueletiforme, com inclusões de anfibólio, evidenciando o processo metamórfico.

\section{2 - Unidades neoproterozóicas}

As unidades estratigráficas neoproterozóicas são os grupos Andrelândia e Dom Silvério, a Suíte Santo Antônio do Grama que inclui os corpos Santo Antônio do Grama (anfibolito) e Córrego do Pimenta (rocha meta-ultramáfica), o Corpo Serra dos Vieiras (granito) e a Suíte Paula Cândido (pegmatito). As unidades litológicas formadas por hidrotermalismo em zonas de cisalhamento também parecem ser de idade neoproterozóica.

\subsection{1 - Grupo Andrelândia}

Esta unidade ocorre predominantemente sob a forma de escamas tectônicas intercaladas no Complexo Juiz de Fora (Fig. 2, 3 e 4). O Grupo Andrelândia, composto essencialmente de paragnaisse granatífero com intercalações de rocha calcissilicática, caracteriza espessa cobertura metassedimentar, cujos protólitos foram sedimentos pelíticos a grauvaquianos (paragnaisse) e, subordinamente, marga (rocha calcissilicática).

O paragnaisse é uma rocha bandada que, em geral, mostra migmatização em intensidades diversas. O bandamento do paragnaisse varia de centimétrico a decimétrico e reflete proporções diversas entre seus minerais félsicos e máficos. Da migmatização resultou a alternância de bandas gnáissicas escuras, compostas de paleossoma ou melanossoma, com bandas de leucossoma granítico. $\mathrm{O}$ bandamento e a foliação geralmente são paralelos e estão nitidamente dobrados. O leucossoma granítico pode ser discordante do bandamento gnáissico e, localmente, chega a predominar sobre o paragnaisse, formando corpos graníticos não mapeáveis nas escalas do trabalho.

O paragnaisse é uma rocha de granulação fina a média e coloração cinza clara a cinza escura. É composto pela associação quartzo + plagioclásio + biotita + granada \pm sillimanita \pm feldspato potássico \pm ortopiroxênio (Tabela 1). A foliação, geralmente paralela ao bandamento e localmente com feições miloníticas, é materializada pela orientação de biotita, sillimanita e/ou granada. Quartzo e plagioclásio ocorrem estirados ao longo da foliação, mas também formam mosaicos granoblásticos. Apresentam evidências de deformação intracristalina expressa sob a forma de extinção ondulante. Porfiroblastos e poiquiloblastos de granada, freqüentemente rotacionados, mostram sombras de pressão assimétricas, indicando seu caráter sincinemático à foliação. Cristais de granada pequenos, intensamente fraturados, estão dispersos na matriz. A sillimanita se mostra em cristais prismáticos alongados. O ortopiroxênio ocorre em pequena quantidade, sob a forma de grãos hipidioblásticos, podendo estar parcialmente substituídos por biotita.

A rocha calcissilicática constitui delgadas camadas ou lentes, paralelas à foliação e ao bandamento do paragnaisse. Trata-se de rocha de granulação muito fina a fina, coloração cinza escura e aspecto maciço, constituída predominantemente por quartzo, plagioclásio cálcico, granada, clinopiroxênio e hornblenda. Os minerais acessórios são apatita, opacos, escapolita, titanita e epidoto.

Dados geocronológicos U-Pb de grãos de zircão, extraídos de uma amostra de paragnaisse, sugerem que a bacia Andrelândia, na região mapeada, recebeu contribuição do arco magmático do Orógeno Araçuaí (ca. 585-630 Ma, Pedrosa-Soares et al. 2011), assim como de fontes mais velhas, e indicam pico metamórfico em torno de $575 \mathrm{Ma}$ (D. Gradim, dissertação de mestrado em andamento). Desta forma, a idade do Grupo Andrelândia na região aqui enfocada ficaria entre $c a .575 \mathrm{Ma}$ (idade do metamorfismo) e ca. $600 \mathrm{Ma}$ (idade do zircão detrítico mais jovem), e representaria uma bacia de antearco.

\subsection{2 - Grupo Dom Silvério}

Esta unidade representa uma associação metavulcano-sedimentar essencialmente composta por xistos diversos, com raras intercalações centimétricas a decimétricas de quartzito. O Grupo Dom Silvério ocorre apenas no setor noroeste da Folha Viçosa (Fig. 3 e 4), em contato tectônico com o Complexo Mantiqueira. As relações de campo indicam que a parte basal do grupo é constituída por hornblenda xisto, o qual representaria um protólito vulcânico máfico (Peres 2000). Em contato brusco com este xisto máfico ocorre uma sucessão pelítica a psamo-pelítica, composta por biotita xisto, mica xisto, granada-biotita xisto, cianita-grafita-micaquartzo xisto e grafita-mica xisto, intercalados em contato gradacional com mica-quartzo xisto e sericita quartzito. O litotipo predominante, entretanto, é representado por granada-biotita xisto, ora mais quartzoso, ora menos. Toda a sucessão apresenta granulação média a grossa e encontra-se intensamente foliada. Os afloramentos do Grupo Dom Silvério apresentam-se, em geral, muito intemperizados. 

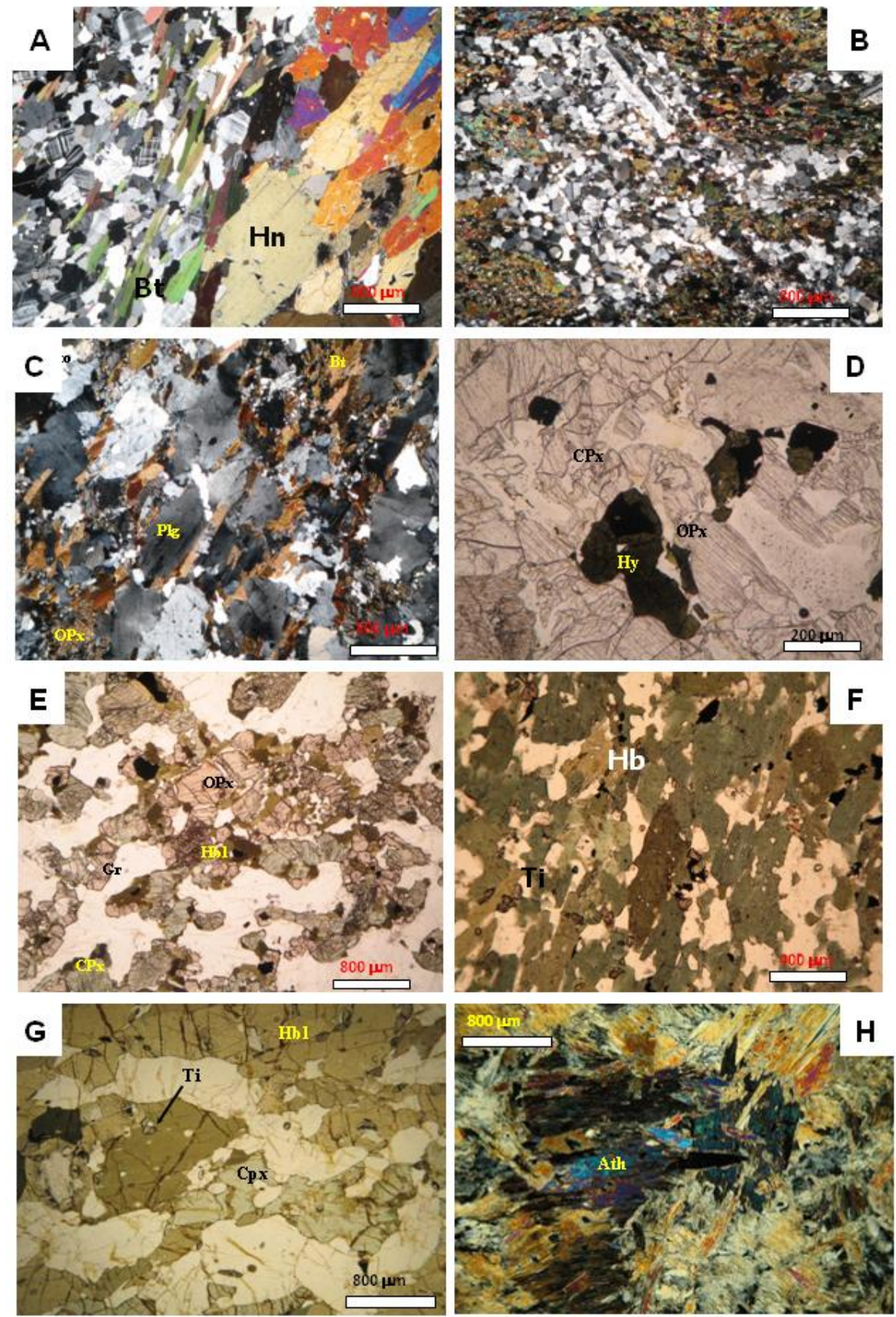

Figura 6. Prancha de fotomicrografias: $A$, contato entre banda máfica, rica em hornblenda (Hn), e félsica, com biotita (Bt), em ortognaisse do Complexo Mantiqueira (nicóis cruzados); B, orto-anfibolito do Complexo Mantiqueira (nicóis cruzados); $C$, ortognaisse enderbítico do Complexo Juiz de Fora, exibindo ortopiroxênio (Opx), biotita (Bt), plagioclásio (Plg) e quartzo (nicóis cruzados); D, granulito ultramáfico do Complexo Juiz de Fora (nicóis paralelos), rico em ortopiroxênio (Opx), clinopiroxênio (Cpx) e hercinita (Hy); E, granulito máfico do Complexo Juiz de Fora (nicóis paralelos), com ortopiroxênio (OPx), clinopiroxênio (Cpx), granada (Gr) e hornblenda (Hbl); F, hornblenda (Hb) xisto do Grupo Dom Silvério (nicóis paralelos); G, ortoanfibolito Santo Antônio do Grama (nicóis paralelos), com hornblenda (Hbl), clinopiroxênio

(Cpx) e titanita (Ti); H, rocha meta-ultramáfica rica em antofilita (Ath) do Corpo Córrego do Pimenta (nicóis cruzados).

Figure 6. Plate of photomicrographies: A, contact between hornblende(Hbl)-rich mafic band and biotite-bearing felsic band in the Mantiqueira Complex orthogneisses (crossed polarizers); $B$, amphibolite from the Mantiqueira Complex (crossed polarizers); $C$, enderbitic gneiss from the Juiz de Fora Complex, showing orthopyroxene (Opx), biotite (Bt), plagioclase (Plg) and quartz (crossed polarizers), D: ultramafic granulite from the Juiz de Fora Complex (parallel polarizers), rich in orthopyroxene (Opx), clinopyroxene (Cpx) and hercynite (Hy); E, mafic granulite from the Juiz de Fora Complex (parallel polarizers), showing orthopyroxene (Opx), clinopyroxene (Cpx), hornblende (Hbl) and garnet (Gr); F, hornblende ( $\mathrm{Hbl}$ ) schist of the Dom Silvério Group (parallel polarizers); G, Santo Antônio do Grama orthoamphibolite (parallel polarizers), showing hornblende (Hbl), clinopyroxene (Cpx) and titanite (Ti); H: anthophyllite-rich meta-ultramafic rock from the Córrego do Pimenta body (crossed polarizers). 
O hornblenda xisto tem hornblenda, quartzo e plagioclásio, como minerais essenciais, e titanita e zircão como acessórios (Fig. 6F). O mica xisto apresenta biotita, quartzo, muscovita, granada e feldspatos, como mineralogia essencial, e cianita, estaurolita, zircão e hornblenda como acessórios (Tabela 1). Amplas variações composicionais podem ocorrem neste pacote.

Nos quartzitos, de modo geral, a sericita é um constituinte comum, enquanto que pequenos cristais de feldspatos são raros. A trama granoblástica predomina, com grandes cristais de quartzo em contato poligonal, mas, fitas (ribbons) de quartzo com extinção ondulante são frequentes.

Dados geocronológicos U-Pb de grãos de zircão, extraídos de uma amostra de hornblenda xisto, indicam uma idade de cristalização magmática em torno de $627 \mathrm{Ma}$, para o protólito máfico deste xisto (D. Gradim, dissertação de mestrado em andamento). Desta forma, a parte mapeada do Grupo Dom Silvério foi depositada no início do Ediacarano (Fig. 3).

\subsection{3 - Suíte Santo Antônio do Grama}

Esta suíte inclui a lasca tectônica representada pelo grande corpo de ortoanfibolito que ocorre nos arredores de Santo Antônio do Grama e a escama tectônica de rocha meta-ultramáfica que compõe o Corpo Córrego do Pimenta (Fig. 2 e 4).

O Anfibolito Santo Antônio do Grama sustenta serras alinhadas na direção NE-SW e N-S, estando em contato tectônico, próximo à Zona de Cisalhamento de Abre Campo, com os ortognaisses dos complexos Mantiqueira e Juiz de Fora e com a cobertura metassedimentar do Grupo Andrelândia, com os quais é estruturalmente concordante (Fig. 2 e 4). O Anfibolito Santo Antônio do Grama, caracteriza-se como orto-derivado (metagabro, Queiroga 2010), apresenta coloração verde escura, granulação média a grossa e venulações quartzofeldspáticas geralmente concordantes com a foliação, mas que podem ser localmente discordantes (Fig. 5E). O anfibolito possui textura granoblástica a nematoblástica e é essencialmente composto por hornblenda (45\%), plagioclásio cálcico (30\%), clinopiroxênio (13\%) e titanita (10\%, Fig. 6G). Os principais minerais acessórios são apatita, quartzo ( $\leq 2 \%)$, sulfetos (calcopirita, pirita e pirrotita) e outros minerais opacos. Sua ortoderivação, a partir de um gabro, é sugerida pela composição mineralógica, abundância de cristais de titanita, atributos litoquímicos e dados isotópicos (Brandalise 1991, Fischel 1998, Queiroga 2010). Datações U-Pb em zircão indicam que a idade de cristalização magmática do Anfibolito Santo Antônio do Grama é ca. 600 Ma e seu metamorfismo regional teve lugar em ca. $575 \mathrm{Ma}$. Os dados Sm-Nd indicam que o protolito foi um gabro juvenil, representante de um ofiolito ediacarano (Queiroga 2010).

O corpo meta-ultramáfico Córrego do Pimenta, que ocorre como escama tectônica alojada no Complexo Mantiqueira próximo à base do metagabro Santo Antônio do Grama, é representada por um antofilita-talco xisto. Esta rocha apreenta-se geralmente saprolitizada, tem coloração acinzentada a esverdeada e é sedosa ao tato (Fig. 5F). Cristais milimétricos a centimétricos de antofilita e talco definem bem a foliação. Sua composição mineralógica é dominada por antofilita, talco e clorita magnesiana (clinocloro). A antofilita ocorre sob a forma de grandes agulhas e às vezes como pequenos prismas (Fig. $6 \mathrm{H}$ ) e envolve massas compostas de cristais aciculares de talco. O clinocloro é comum nos interstícios entre a antofilita e o talco.

\subsection{4 - Corpo Serra dos Vieiras}

Esta unidade encontra-se exclusivamente na porção central da Folha Jequeri (Fig. 2 e 4), aflorando como maciços rochosos e pães-de-açucar, geralmente alongados na direção NE-SW, ou em lajedos. O Corpo Serra dos Vieiras é um conjunto de granitos foliados, provenientes da fusão parcial do paragnaisse Andrelândia. Por isto, este corpo granítico é correlacionável a supersuíte G2 que engloba o plutonismo sincolisional do Orógeno Araçuaí (Pedrosa-Soares et al. 2011).

Em afloramento o granito Serra dos Vieiras apresenta coloração rosada e bandamento milimétrico. É composto por microclina (45\%), quartzo (35\%), plagioclásio (5-10\%), biotita, muscovita e granada que, juntas, somam cerca de 15\% (Tabela 1). Desta forma, a composição do Corpo Serra dos Vieiras varia de álcali-feldspato granito a sienogranito. A foliação é concordante com o delgado bandamento e marcada pela orientação de biotita, muscovita, quartzo e granada.

\subsection{5 - Suíte Paula Cândido}

Esta suíte pegmatítica situa-se na porção sudoeste da Folha Viçosa (Fig. 3). Inclui rochas leucocráticas, compostas por feldspato potássico, quartzo, muscovita, biotita e rara turmalina, de granulação grossa a muito grossa, com textura gráfica localizada. Estes pegmatitos ocorrem na forma de stocks, diques e veios, apresentando contatos bruscos e escalonados com o ortognaisse do Complexo Mantiqueira. Xenólitos decimétricos a métricos, de formas variadas, do ortognaisse Mantiqueira são comuns no interior dos pegmatitos Paula Cândido. Fraturas ocorrem com freqüência comumente, mas não se observa foliação (nem onde há mais mica). Embora não existam dados 
geocronológicos para esta suíte, sua idade é interpretada como ediacarana a cambriana, a exemplo dos demais distritos pegmatíticos do Orógeno Araçuaí (Pedrosa-Soares et al. 2011).

\subsection{6 - Hidrotermalitos}

Os corpos de hidrotermalitos estão intimamente ligados às zonas de cisalhamento de Ponte Nova e Abre Campo (Fig. 2,3 e 4). As ocorrências variam de pontuais a corpos de dimensões quilométricas a hectométricas, com espessuras mal definidas, alongados na direção da foliação dessas zonas de cisalhamento, foliados e fraturados. Em análise de campo, pode-se separar os hidrotermalitos em dois tipos: quartzoso e ferruginoso. Os hidrotermalitos quartzosos possuem granulação grossa, textura sacaróide e são compostos essencialmente por quartzo, tendo micas e/ou feldspatos como minerais acessórios (Fig. 5G). Os hidrotermalitos ferruginosos são corpos de pequenas dimensões, de granulação grossa, foliados a bandados, fraturados, compostos essencialmente por quartzo, magnetita e hematita (Fig. 5H). Enquanto o hidrotermalito quartzoso é comum na Zona de Cisalhamento de Abre Campo, o hidrotermalito ferruginoso só foi encontrado na Zona de Cisalhamento de Ponte Nova, no Complexo Mantiqueira (Fig. 3 e 4).
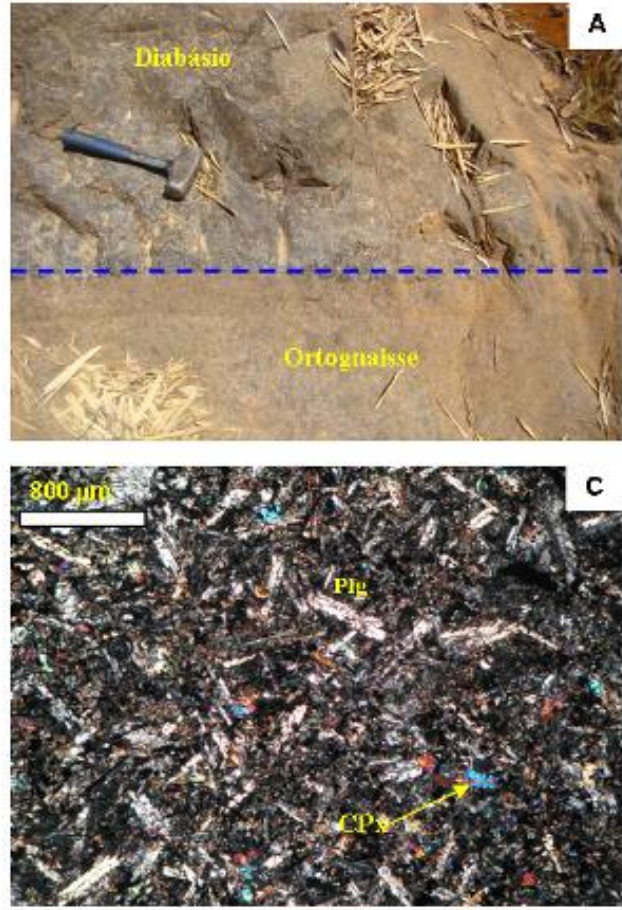

\section{3 - Diques Máficos}

Essas rochas sempre ocorrem encaixadas em estruturas rúpteis, orientados nas direções N-S, NESW e NW-SE, e intrudem todas as unidades anteriormente descritas. Este contato é geralmente brusco e se faz ao longo de planos de fraturas (Fig. 7A). Nas bordas de diques é possível observar disjunções colunares, cujos planos são sempre perpendiculares ao contato do dique. Estas rochas máficas estão livres de deformação e não há indícios de interferência dessas intrusões na estruturação dúctil das rochas encaixantes, isto é, a foliação das encaixantes não sofreu mudança de atitude nas proximidades do contato com os diques máficos.

Os diques são de diabásio, apresentam coloração verde escura e granulação variável entre muita fina e fina. Esta variação de granulação ocorre da borda para o centro, no sentido da cristalização ígnea. A borda do corpo é geralmente afanítica (Fig. 7B). Rumo ao centro do dique, os cristais se tornam cada vez maiores (Fig. 7C e 7D). O diabásio é composto, essencialmente, por cristais ripiformes de plagioclásio maclado e clinopiroxênio. Minerais opacos são os acessórios comuns (Tabela 1). É uma rocha que não apresenta nenhum vestígio de metamorfismo, mostrando textura intergranular.
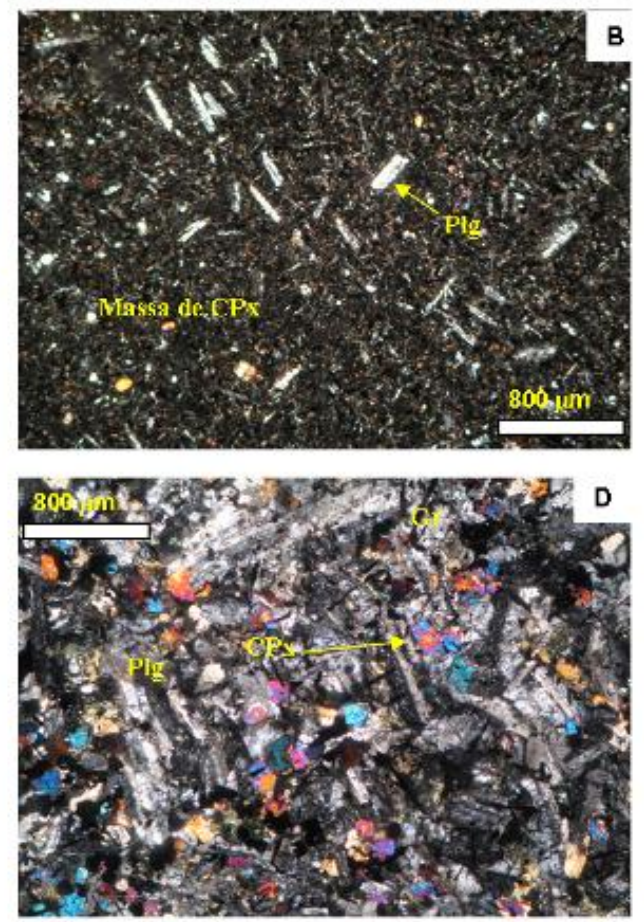

Figura 7. Feições macro e microscópicas de um dique de diabásio. A, dique de diabásio em contato com o ortognaisse do Complexo Mantiqueira; $B$, basalto na borda do corpo, com granulação extremamente fina; $C$, basalto com textura intergranular na posição intermediária do corpo, com granulação um pouco maior que a anterior; $D$, diabásio no centro do corpo. CPx, clinopiroxênio; Plg, plagioclásio.

Figure 7. Macroscopic and microscopic features of a diabase dike. A, contact between the diabase dyke and Mantiqueira orthogneiss; $B$, very-fine grained basalt facies close to the contact; $C$, basalt with intergranular texture in an intermediate location inside the dyke, showing granulation coarser than the border basalt; $D$, diabase texture in the core of the dyke. CPx, clinopyroxene; Plg, plagioclase. 


\section{GEOLOGIA ESTRUTURAL E METAMORFISMO}

A análise das estruturas identificadas na região mapeada implica na atuação de três etapas deformacionais dúcteis $\left(D_{1}, D_{2}\right.$ e $\left.D_{3}\right)$ e uma etapa rúptil tardia. A etapa $D 1$ resultou em transporte tectônico para norte, enquanto D2 imprimiu uma vergência dirigida para oeste. Considera-se que estas etapas deformacionais aconteceram durante 0 período sincolisional do Orógeno Araçuaí, entre 585 Ma e 560 Ma (Alkmim et al. 2007, Pedrosa-Soares et al. 2007, 2011). A terceira fase deformacional (D3) se manifestou em seguida ao encurtamento crustal D1-D2, quando ocorreu o escape lateral de massa, hoje materializado nas grandes zonas de cisalhamento regionais de direção NNE-SSW (e.g., Zona de Cisalhamento de Ponte Nova, Noce et al. 2003, 2007; Alkmim et al. 2007). Estas zonas de cisalhamento provavelmente foram geradas no intervalo entre 560 Ma e 535 Ma (Costa et al. 1998, Peres et al. 2004, Alkmim et al. 2006).

As fraturas são relacionadas essencialmente à tectônica divergente mesozóico-cenozóica, ligada à abertura do Oceano Atlântico.

\section{1 - Estruturas dúcteis}

As unidades geológicas envolvidas na estruturação tectônica da área pertencem a diferentes idades, do Paleoproterozóico e do Neoproterozóico. Diversos autores citam uma fase de deformação mais antiga que afetaria os complexos Mantiqueira e Juiz de Fora (e.g., Heilbron et al. 2003, Noce et al. 2007a,b). Contudo, tais unidades exibem um acervo estrutural que reflete a última deformação, associada à Orogenia Brasiliana, responsável pela obliteração total de estruturas mais antigas. Desta forma, as estruturas dúcteis adiante descritas são todas consideradas como resultantes da deformação brasiliana. Este evento confeccionou uma vasta gama de estruturas dúcteis. A partir da análise destas estruturas foram interpretadas três etapas (ou fases) deformacionais $\left(D_{1}, D_{2}\right.$ e $\left.D_{3}\right)$.

A fase $D_{1}$ é representada pela foliação $S_{1}$, a lineação de estiramento mineral nela contida $\left(L_{1}\right)$ e dobras intrafoliais. Esta fase está bem marcada nas rochas do Complexo Mantiqueira e Grupo Dom Silvério. A foliação $S_{1}$ apresenta baixo ângulo de mergulho (Fig. 8A) e é materializada pela orientação preferencial de mica e anfibólio, assim como pelos ribbons de quartzo e porfiroclastos de feldspato que imprimem texturas miloníticas bem desenvolvidas em rochas do Complexo Mantiqueira. Nos xistos do Grupo Dom Silvério, a foliação $S_{1}$ ocorre paralelamente ao acamamento reliquiar, e no ortognaisse Mantiqueira está disposta paralelamente ao bandamento gnáissico. A lineação de estiramento mineral $\left(L_{1}\right)$ é marcada pelo alongamento dos cristais de quartzo, mica, feldspato e anfibólio, tem caimento sub-horizontal, com máximos para norte e sul (Fig. 8B). Dobras $D_{1}$ são raras e se apresentam muito obliteradas e com flancos rompidos. Ocorrem em diversas escalas, são intrafoliais e apresentam eixos com caimentos variados, que estão distribuídos em uma guirlanda W-E (Fig. 8C). Os indicadores cinemáticos evidenciam transporte tectônico para norte durante a fase $D_{1}$.

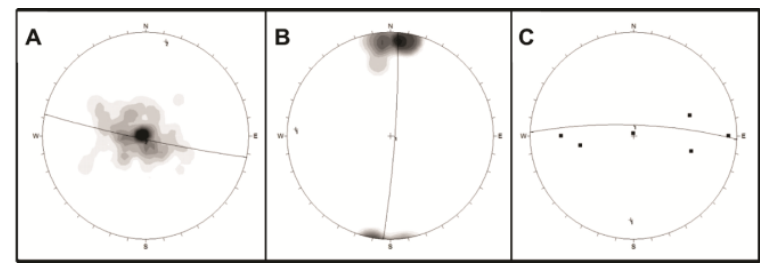

Figura 8. A: diagrama de pólos de $S_{1}, 149$ medidas, máximo 097/06. B: diagrama de $L_{1}, 27$ medidas, máximo 003/05. C: diagrama de eixos de dobra, 6 medidas.

Figure 8. A: Pole diagram for $S_{1}, 149$ measures, maximum 097/06. $B$ : diagram for $L_{1}, 27$ measures, maximum 003/05. C: diagram of fold axes, 6 measures.

$A$ fase $D_{2}$ é restrita à porção central da área mapeada (Fig. 3 e 4). Está mais desenvolvida nas rochas do Complexo Mantiqueira, e é representada pela foliação $\left(S_{2}\right)$ e a lineação de estiramento mineral nela contida $\left(L_{2}\right)$. A foliação $S_{2}$ apresenta mergulhos médios (entre $30^{\circ}$ e $50^{\circ}$ ) para leste (Fig. 9A) e é expressa pela orientação preferencial de mica, anfibólio e quartzo. Assim como $S_{1}$, a foliação $S_{2}$ também apresenta caráter milonítico. A lineação de estiramento mineral $\left(L_{2}\right)$ é marcada pelo alongamento de quartzo, mica e feldspato, em posição down dip, com máximos para leste e nordeste (Fig. 9B). Dobras $D_{2}$ são freqüentes em diversas escalas e mostram nítida vergência para $W$. Desenvolvem-se sobre a foliação $S_{1}$ ou sobre o bandamento paralelo a esta foliação. Seus eixos têm caimento ora para NNE, ora SSW (Fig. 9C). O transporte tectônico geral associado a $D_{2}$ foi de leste para oeste.

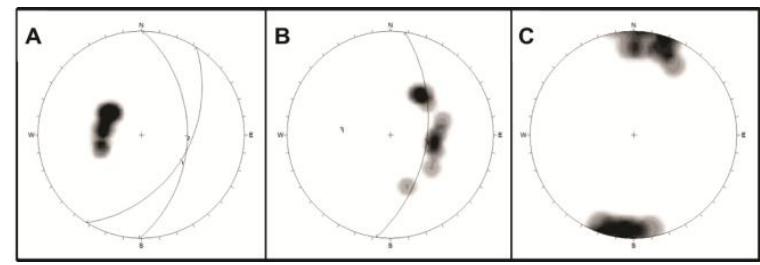

Figura 9. A: diagrama de pólos de $S_{2}, 26$ medidas, máximos 090/45 e 122/50. B: diagrama de $L_{2}, 11$ medidas, máximos 098/45 e 040/35. C: diagrama de eixos de dobra, 15 medidas, máximos 187/06 e 018/02.

Figure 9. A: pole diagram for $S_{2}, 26$ measures, maximum 090/45 and 122/50. B: diagram for $L_{2}, 11$ measures, maximum 098/45 and 040/35. C: diagram of fold axes, 15 measures, maximum 187/06 and 018/02. 
A fase $D_{3}$ é interpretada como uma progressão deformacional da fase $D_{2}$. A foliação $S_{3}$ se apresenta com elevado ângulo de mergulho (superior a $50^{\circ}$ ), no sentido leste (Fig. 10A) e está intimamente ligada ao domínio da Zona de Cisalhamento de Abre Campo (Fig. 2, 3 e 4). Esta zona de cisalhamento é uma faixa de elevada espessura, complexa, que corta toda a porção oeste da área mapeada . A foliação $S_{3}$ tem caráter milonítico em todas as rochas dos complexos Mantiqueira e Juiz de Fora, Grupo Andrelândia, Anfibolito Santo Antônio do Grama e Granito Serra dos Vieiras. As texturas miloníticas são evidenciadas pelos porfiroclastos, sigmoidais ou não, de granada, quartzo, feldspato e piroxênio, agulhas e fitas de quartzo subgranulado e com forte extinção ondulante, e feldspato cominuído, com maclas deformadas, estirados paralelamente à foliação $S_{3}$ e lineação $L_{3}$. A lineação $\left(L_{3}\right)$, materializada pelo estiramento de quartzo, mica, anfibólio, feldspato, piroxênio e granada, é do tipo direcional (strike), com caimento ora para NNE, ora para SSW (Fig. 10B). As relações de $L_{3}$ e $S_{3}$, e seus indicadores cinemáticos, evidenciam que a Zona de Cisalhamento de Abre Campo é do tipo transpressiva destral, com transporte tectônico do bloco superior dirigido para SW. Eventualmente, blocos com cinemática contrária são encontrados, fato que é absolutamente normal em zonas de cisalhamento regionais. Dobras associadas a $D_{3}$ são corriqueiras $e$ apresentam as mesmas características das dobras referentes à fase $D_{2}$ (Fig. 10C), sendo que a diferença básica entre elas é o ângulo de mergulho da superfície axial, que é superior nas dobras $D_{3}$.

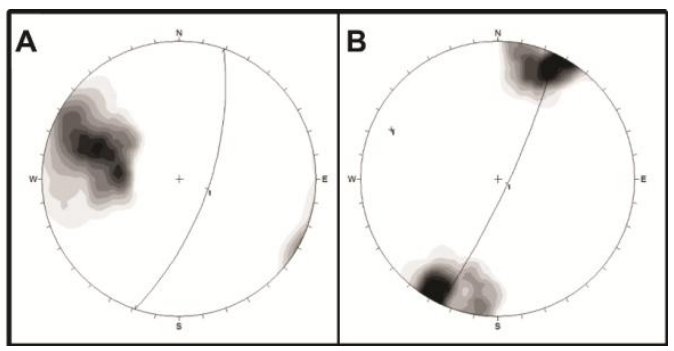

Figura 10. A: diagrama de pólos de $S_{3}, 185$ medidas, máximo 118/64. B: diagrama de $L_{3}, 38$ medidas, máximos 023/07 e 204/06.

Figure 10. A: pole diagram of $S_{3}, 185$ measures, maximum 118/64; B: diagram $L_{3}, 38$ measures, maximum 023/07 and 204/06.

\subsection{Metamorfismo}

Os litotipos do Complexo Mantiqueira apresentam associações mineralógicas indicativas de metamorfismo de fácies anfibolito alto. No ortognaisse bandado, os minerais que estão em equilíbrio na paragênese do metamorfismo progressivo são quartzo, plagioclásio, microclina, hornblenda e biotita. A paragênese metamórfica, em conjunto com a marcante migmatização e a ausência de muscovita primária, situam o metamorfismo do ortognaisse Mantiqueira na zona da anatexia da fácies anfibolito. $\mathrm{O}$ granada anfibolito apresenta a paragênese hornblenda marrom-esverdeada + plagioclásio + clinopiroxênio + granada rosada. Esta associação, de acordo com Yardley (2004), é de caráter transicional entre as fácies anfibolito e granulito.

Os litotipos do Complexo Juiz de Fora mostram paragêneses minerais compatíves com a fácies granulito, reestabilizadas em fácies anfibolito. 0 ortognaisse enderbítico apresenta a paragênese progressiva ortopiroxênio + quartzo + plagioclásio, característica da fácies granulito. Anfibólio e biotita são minerais retrógrados, formados às custas do piroxênio. Desta forma, a rocha atingiu seu pico metamórfico em fácies granulito e, por hidratação de um sistema anidro, foi retrometamorfizada em fácies anfibolito. $O$ granulito máfico mostra a paragênese progressiva plagioclásio + ortopiroxênio + clinopiroxênio + granada. De acordo com Yardley (2004), a coexistência de ortopiroxênio e clinopiroxênio em metabasitos é diagnóstica da fácies granulito de média pressão. A hornblenda do granulito máfico também representa retrometamorfismo em fácies granulito. Por fim, os granulitos ultramáficos também mostram paragênese progressiva típica de rochas granulíticas, com ortopiroxênio + hercynita, re-equilibrada em fácies anfibolito, como indica a associação anfibólio + clinocloro. Em síntese, o Complexo Juiz de Fora exibe metamorfismo progressivo na fácies granulito de média pressão e retrometamorfismo em fácies anfibolito.

O corpo de anfibolito Santo Antônio do Grama mostra uma paragênese mineral (hornblenda marrom-esverdeada + clinopiroxênio + plagioclásio) típica da fácies anfibolito alto. A substituição de clinopiroxênio por anfibólio indica retrometamorfismo em fácies anfibolito médio.

As rochas do Grupo Andrelândia apresentam associações mineralógicas indicativas de metamorfismo na transição de fácies anfibolitogranulito. Nos termos mais aluminosos (pelíticos) a paragênese progressiva em equilíbrio é sillimanita + granada + ortopiroxênio, indicativa de fácies granulito. De fato, Yardley (2004) afirma que sillimanita prismática bem desenvolvida, como é o caso das rochas em questão, é em geral restrita à fácies granulito. Contudo, biotita é onipresente no Grupo Andrelândia, assim como os leucossomas graníticos, evidenciando que o metamorfismo predominante deve ser situado na transição de fácies anfibolito-granulito.

As associações mineralógicas dos xistos pelíticos do Grupo Dom Silvério indicam que a xistosidade 
originou-se em fácies anfibolito médio, zona da cianita.

\section{3 - Estruturas Rúpteis}

As fraturas possuem direções dispersas, usualmente com mergulhos altos e não raramente verticais, com espaçamento milimétrico a decimétrico. A despeito desta dispersão, direções preferenciais foram identificadas a NE, NW e WNW (Fig. 11). As fraturas são mais freqüentes em rochas de granulação mais fina, ricas em minerais máficos. Os diques básicos são sempre mais fraturados que suas encaixantes.

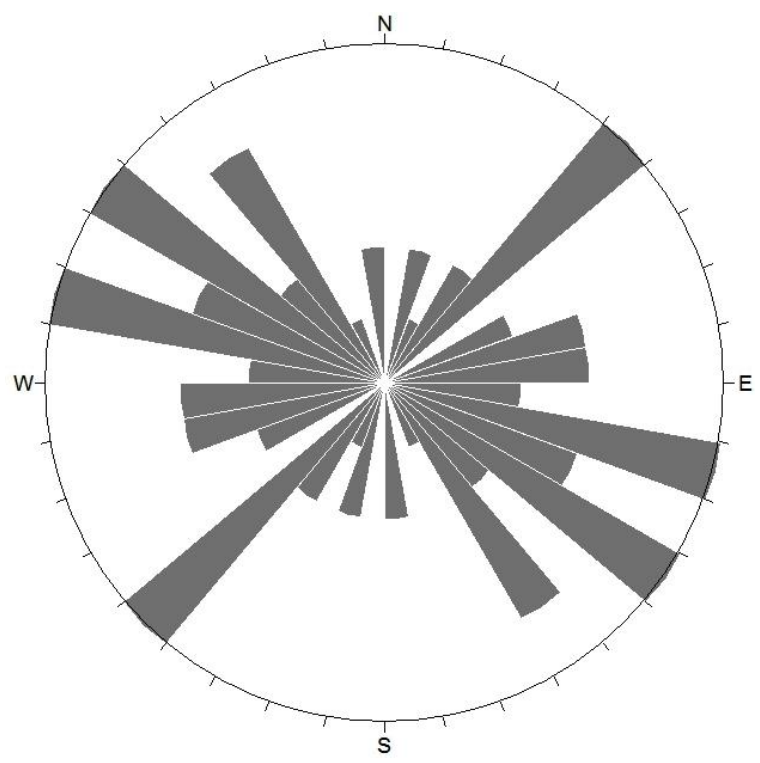

Figura 11. Diagrama de roseta da direção dos planos de fratura, 44 medidas, com pétalas dominantes a N45E, N75W e N55W.

Figure 11. Rosette diagram for the strike of fracture surfaces, 44 measures, with dominant petals N45E, N75W and N55W.

\section{CONCLUSÃO}

A região de Jequeri-Viçosa encerra uma longa e atrativa história geológica. A Zona de Cisalhamento (ou Descontinuidade) de Abre Campo tem sido interpretada como uma sutura paleoproterozóica resultante da amalgamação dos arcos Mantiqueira e Juiz de Fora, que foi retomada durante a Orogenia Brasiliana e serviu também de sutura para o Orógeno Araçuaí (e.g., Alkmim et al. 2006, Noce et al. 2007). De fato, a região estudada apresenta um grande corpo ofiolítico ediacarano, o Anfibolito Santo Antônio do Grama, envelopado pela Zona de Cisalhamento de Abre Campo (Queiroga 2010). A leste desta zona de cisalhamento ocorre o arco magmático do Orógeno Araçuaí (Pedrosa-Soares et al. 2011), indicando que a subducção brasiliana foi de oeste para leste (na geografia atual). Desta forma, seria de se esperar que a área de JequeriViçosa contenha algum remanescente de bacia orogênica brasiliana, pois se situa na região de antearco do Orógeno Araçuaí. Os estudos aqui apresentados e os dados geocronológicos U-Pb de $\mathrm{D}$. Gradim (dissertação de mestrado em andamento) evidenciam que o paragnaisse Andrelândia, rico em palgioclásio, e rochas metavulcânicas (anfibólio xistos) do Grupo Dom Silvério são candidatos fortes a representar depósitos orogênicos em bacia antearco e/ou flysch.

Os complexos do embasamento portam anfibolitos diversos, cujos protólitos seriam rochas ígneas máficas. Entretanto, o granada anfibolito do Complexo Mantiqueira deixa dúvidas quanto a sua gênesee tanto pode representar rocha ígnea paleoproterozóica ou mais jovem, quanto pode ser o resultado do metamorfismo de mistura pelitocarbonatada.

Os pegmatitos da Suíte Paula Cândido são intrusivos no Complexo Mantiqueira, mas, mesmo assim, poderiam representar massas ígneas resultantes da fusão parcial deste complexo em profundidade, durante a Orogenia Brasiliana.

Em termos tectônicos, a região estudada registra as principais fases evolutivas do Orógeno Araçuaí, mas o acervo estrutural do embasamento foi completamente re-moldado pela Orogenia Brasiliana. As fases tectônicas com transporte para norte $\left(D_{1}\right)$ e oeste $\left(D_{2}\right)$, assim como o escape lateral destral para SW $\left(D_{3}\right)$, reportadas por Peres et al. (2004) e Alkmim et al. (2006, 2007), são perfeitamente reconhecidas na região de JequeriViçosa.

Finalmente, os estudos realizados contribuíram para esclarecer, definitivamente, a natureza dos corpos de "quartzito" sempre associados à zonas de cisalhamento e presentes tanto no embasamento quanto na cobertura pré-cambriana. Estes corpos representam o produto de hidrotermalismo intenso em zonas de cisalhamento, originando uma rocha muito rica em quartzo, com típica textura sacaroidal, que se denominou hidrotermalito quartzoso. A formação ferrífera envelopada pelo Complexo Mantiqueira na Zona de Cisalhamento de Ponte Nova também é um hidrotermalito e constitui pequenos, mas significativos, depósitos de ferro.

\section{AGRADECIMENTOS}

Os autores dedicam este trabalho ao geocientista entusiástico e grande amigo, Carlos Maurício Noce. Agradecem à CPRM pelo contrato que permitiu o mapeamento das folhas Jequeri e Viçosa; à CAPES, pela bolsa de mestrado do primeiro autor; à FAPEMIG, pela bolsa de doutorado de T. Novo; ao CNPq, pelas bolsas de produtividade em pesquisa de Alkmim, Noce e Pedrosa-Soares; ao CPMTC, pela infraestrutura e apoio laboratorial; e aos revisores anônimos de GEONOMOS. 


\section{REFERÊNCIAS}

Alkmim F.F., Marshak S., Pedrosa-Soares A.C., Peres G.G., Cruz S.C.P., Whittington A. 2006. Kinematic evolution of the Araçuaí-West Congo orogen in Brazil and Africa: Nutcracker tectonics during the Neoproterozoic assembly of Gondwana. Precambrian Research, 149: 43-63.

Alkmim F.F., Pedrosa-Soares A.C., Noce C.M. \& Cruz S.C.P. 2007. Sobre a evolução tectônica do Orógeno Araçuaí-Congo Ocidental. Geonomos, 15: 25-43.

Almeida F.F.M., Brito-Neves B.B., Carneiro C.D.R. 2000. The origin and evolution of the South American platform. Earth Science Review, 50: 77-111.

Brandalise L.A. 1991. Folha Ponte Nova, SF.23-X-B-II, escala 1:100.000. Programa de Levantamentos Geológicos Básicos do Brasil. Brasília, DNPM/CPRM, 194p.

Brito Neves B.B., Campos-Neto M.C. \& Fuck R. 1999. From Rodinia to Western Gondwana: an approach to the Brasiliano-Pan African cycle and orogenic collage. Episodes, 22: 155-199.

Costa A.G. 1998. The granulite-facies rocks of the northern segment of the Ribeira Belt, Eastern Minas Gerais, SE Brazil. Gondwana Research, 1: 367-372.

Fischel D.P. 1998. Geologia e dados isotópicos Sm-Nd do Complexo Mantiqueira e do Cinturão Ribeira na região de Abre Campo, Minas Gerais. Dissertação de Mestrado, Instituto de Geociências, Universidade de Brasília, 98p.

Gradim D.T., Noce, C.M., Novo T.A., Queiroga G.N., PedrosaSoares A.C., Suleimam M.A., Martins M. 2011. Folha Viçosa SF-23-X-B-V, escala 1:100.000. Contrato CPRM-UFMGPrograma Geologia do Brasil.

Heilbron M. \& Machado N. 2003. Timing of terrane accretion in the Neoproterozoic-Eopaleozoic Ribeira orogen (SE Brazil). Precambrian Research, 125: 87-112.

Heilbron M.L., Pedrosa-Soares A.C., Campos-Neto M.C., Silva L.C., Trouw R. \& Janasi V.A. 2004. Província Mantiqueira. In: V.M. Mantesso-Neto, A. Bartorelli, C.D.R. Carneiro \& Brito-Neves, B.B. (orgs.). Geologia do Continente Sul-Americano.São Paulo, Editora Beca, p. 203-234

Leite C.A.S., Perrotta M.M., Silva L.C., Silva M.A., Heineck C.A., Salvador E.D., Vieira V.S., Silva M.G.M., Drumond J.B.V., Malouf R.F., Lacerda-Filho J.V., Valente C.R., Gomes S.D., Sachs L.L.B., Oliveira I.W.B., Ramgrab G.E., Netto C., Junqueira P.A., Paes V. 2004. Folha SF.23 - Rio de Janeiro.
Carta Geológica do Brasil ao Milionésimo, CPRM, Programa Geologia do Brasil.

Noce C.M., Pedrosa-Soares A.C., Silva L.C., Alkmim F.F. 2007a. O Embasamento Arqueano e Paleoproterozóico do Orógeno Araçuaí. Geonomos, 15: 17-23.

Noce C.M., Pedrosa-Soares A.C., Silva L.C., Armstrong R. \& Piuzana D. 2007b. Evolution of polyciclic basement complexes in the Araçuaí orogen, based on U-Pb SHRIMP data: Implications for Brazil-Africa links in Paleoproterozoic time. Precambrian Research, 159: 60-78.

Pedrosa-Soares, A.C., Noce, C.M., Wiedemann, C.M., Pinto, C.P. 2001. The Araçuaí-West Congo orogen in Brazil: An overview of a confined orogen formed during Gondwanland assembly. Precambrian Research, 110: 307-323.

Pedrosa-Soares A.C., Noce C.M; Alkmim F.F., Silva L.C., Babinski M., Cordani U., Castañeda C. 2007. Orógeno Araçuaí: síntese do conhecimento 30 anos após Almeida 1977. Geonomos, 15 (1): 1-16.

Pedrosa-Soares A.C., De Campos C., Noce C.M., Silva L.C., Novo T., Roncato J., Medeiros S., Castañeda C., Queiroga G., Dantas E., Dussin I., Alkmim F.F. 2011. Late NeoproterozoicCambrian granitic magmatism in the Araçuaí orogen (Brazil), the Eastern Brazilian Pegmatite Province and related mineral resources. Geological Society, London, Special Publications, 350: 25-51.

Peres G.G. 2000. O Grupo Dom Silvério na região leste de Minas Gerais: arcabouço estrutural e evolução tectônica. Departamento de Geologia, Universidade Federal de Ouro Preto, Dissertação de Mestrado, 125 p.

Peres G.G., Alkmim F.F., Jordt-Evangelista H. 2004. The southern Araçuaí belt and the Dom Silvério Group: geologic architecture and tectonic significance. Anais Academia Brasileira de Ciências, 76: 771-790.

Queiroga G.N. 2010. Caracterização dos restos de litosfera oceânica do Orógeno Araçuaí entre os paralelos $17^{\circ}$ e $21^{\circ} \mathrm{S}$. Instituto de Geociências, Universidade Federal de Minas Gerais, Tese de Doutoramento, 180 p.

Queiroga G.N., Gradim D.T., Pedrosa-Soares A.C., Pinho R.R., Vilela F., Noce C.M., Nola T., Novo T.A., Suleimam M.A., Basto C.F. 2011. Folha Jequeri SF-23-X-B-II-4, escala 1:50.000. Contrato CPRM-UFMG-Programa Geologia do Brasil.

Yardley B.W.D. 2004. Introdução à petrologia metamórfica (Tradução Reinhardt A. Fuck). Editora UnB, 434 p. 